\begin{tabular}{|c|c|}
\hline \multirow{3}{*}{ 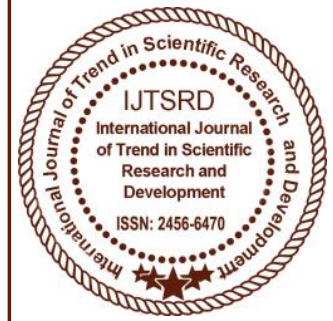 } & $\begin{array}{l}\text { International Journal of Trend in Scientific } \\
\text { Research and Development (IJTSRD) }\end{array}$ \\
\hline & UGC Approved International Open Access Journal \\
\hline & ISSN No: 2456 - 6470 | www.ijtsrd.com | Volume - 1 | Issue - 5 \\
\hline
\end{tabular}

\title{
Mahatama Gandhi National Rural Employment Guarantee Scheme (MGNREGS)
}

\author{
(A Study of Erstwhile Block Keller of District Pulwama in J \&K)
}

\author{
Mohd Ashraf Mir \\ Research Scholar (Ph .D), \\ Jiwaji University Gwalior
}

\author{
Dr. Vibha Doorwar \\ Assistant Professor, \\ MLB College Gwalior
}

\author{
Dr. Syed Damsaz Ali Andrabi \\ Social Scientist, Department of \\ Higher Education, J\& K
}

\begin{abstract}
Rural Employment Guarantee Act was notified on September 7, 2005, now referred to as MGNREGA was launched on 2 February 2006 in 200 backward districts with a view to extends it to all the districts within five years and extended throughout India wef, 01- 04 - 2008. It was expanded to cover another 130 districts in 2007-2008 and eventually covered all districts in India wef April 01, 2008.
\end{abstract}

As envisaged in the Act, the Jammu and Kashmir Rural Employment Guarantee Scheme has been formulated on the basis of the Guidelines issued by the Ministry of Rural Development, Government of India. The flagship scheme was extended to the State wef February 2006 as per following roaster:

1. Doda, Poonch, Kupwar are Ist generation NREGA districts of J\&K wef 2-2006)

2. Anantnag and Jammu are $2^{\text {nd }}$ generation NREGA districts of J\&K wef 04-2007)

3. Rest of the Districts (17) including District Pulwama are 3rd generation NREGA districts of J\&K wef 04-2008)

Keywords: Permissible works, Negative works, Poverty Alleviation, Wage Employment, Participatory Identification of Poor

\section{INTRODUCTION}

After India's independence the first ever developmental programme launched was Community Development Programme (CDP in 1952) followed by a series of welfare programmes via NES, FFW, IRDP, SFDA, MFDA, TRYSEM, DWCRA, SITRA, RLEGP,JRY , EAS , SGSY , JGSY, WS, IAY, PDS ,CRSP,TSC,NBA, IAY, NRLM , DPAP, DDP, IWMP, IWDP, BRGF and MGNREGA.

MGNREGA broadly figures in Wage Employment categories aimed at enhancing the livelihood security of the people in the rural areas by guaranteeing 100 days of wage employment in a financial year to a rural household whose adult members are ready to do unskilled manual work. For the first time in India, it recognized the right to work as fundamental legal right. The significance of the MGNREGA lies in the fact that it creates a right-based framework for wage employment programmes and makes the government legally accountable for providing employment to those who demand for it. In this way, the legislation went beyond providing a social safety net towards guaranteeing the right to employment.

Besides providing 100 days of guaranteed employment in a financial year to every poor rural household, it also aimed at developing rural infrastructure by undertaking the generation of wage 
employment schemes that addressed the cause wrong social safety net for the vulnerable groups in rural areas by providing a fall-back employment source, when other employment alternatives are scarce or inadequate. The auxiliary objective is to strengthen the natural resource base of rural livelihood and to create durable assets in rural areas. The outcome of this act is creating a model of governance reform anchored on the principles of right to livelihood, transparency and grass root democracy.

This Act is a revolutionary step as it is the only programme in the world which guaranteed employment at such an unprecedented scale. This Act is also a hope for majority of Indian population, which lived on less than rupees 20 per day in gaining adequate and dignified livelihood. This Act is an effort in the direction of providing the citizens, men and women equally, the right to an adequate means to livelihood. This Act could also be used to realize concealed potential saving, represented by huge army of unemployed/ underemployed/ disguisedly employed rural population to develop planned and equitable rural infrastructure. Youth of our country in the absence of useful employment could not be allowed to degenerate and take the life of crime, unrest and riots and this Act was helpful in preventing a crime and curb migration for employment.

MGNREGA is a significant legislation in many ways. Unlike earlier employment schemes, it is demand driven. People who needed jobs would demand them which the government is legally bound to provide. In case of failure to do so, the government has to provide them unemployment allowance. For the first time, rural communities were given not just a development programme, but also a regime of rights.

The MGNREGA is not just about creating employment but also about developing the social infrastructure. The assets created under the Act will be a step towards growth through higher investment in rural infrastructure. The potential for labour-intensive public works in the field of environmental protection is massive; this includes areas such as watershed development, land regeneration, prevention of soil erosion, restoration of tanks, protection of forests and related activities. Expenditure on the MGNREGA schemes will yield dividends not only in terms of economic activity in the present but also by improving the conditions of production in rural areas in the future.
Prime objectives of the Act are,

(i) To boost the rural economy.

(ii) To enhance overall economic growth.

(iii) To enhance the livelihood security of the households in rural areas by providing at least 100 days of guaranteed wage employment in every financial year to every household whose adult members volunteer to do unskilled manual work.

(iv) Creation of Durable Assets.

(v) Deepening Democracy.

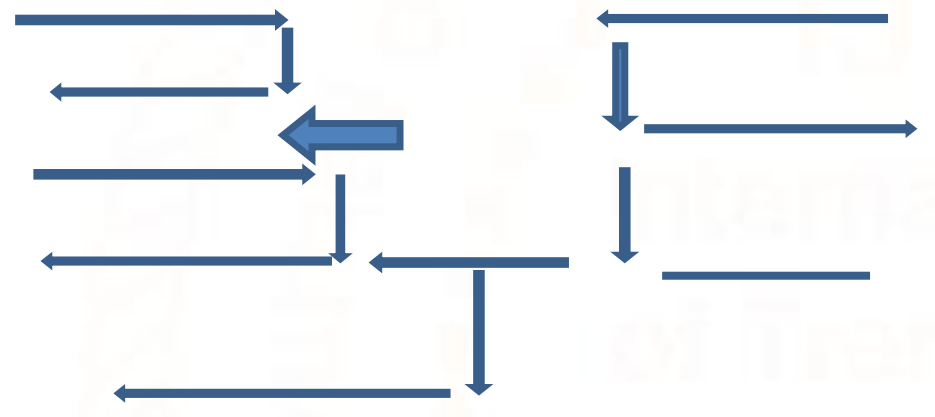

\section{SOCIAL AUDIT:}

An innovative feature of the Mahatma Gandhi NREGA is that it has institutionalized 'Social Audit' as a mean of continuous public vigilance (Mahatma Gandhi NREGA, Section 17), Social Audit has the following dimensions:

i) As a continuous and ongoing process, involving public vigilance and verification of quantity and quality of works at different stages of implementation; and

ii) A process is to be conducted in every Gram Panchayat (GP) at least once in six months, involving a mandatory review of all aspects.

The basic objective of Social Audit is to ensure public accountability in the implementation of projects, laws and policies.

Social Audit is an effective means for ensuring transparency, participation, consultation and accountability under MGNREGA. The process of Social Audit combines people's participation and monitoring with the requirements of the audit discipline. Since the agency implementing the 
Scheme cannot itself audit the Scheme, therefore, it is necessary to promote people's participation in the audit along with support provided by an independent social audit organisation that will facilitate the process.

The Social Audit process is not a fault finding, but a fact finding process. The work of the Auditor is only to investigate by cross-verifying facts and details in the records from the labourers and cross verifying works at site. The "Auditors" must not view themselves as "Prosecutors". In addition there is specific provision for worksite facilities in the Act.

\section{Data Analysis and Interpretation:}

The panchayat halqas namely Achgoose, Arigam B, Drabgam B, Kalampora, Nikas and Sangerwani,A ,in respect of those whose data has been provided on the basis of Simple Random sampling which is more than $10 \%$ of Universe.

\section{MAINTENANCE OF RECORDS}

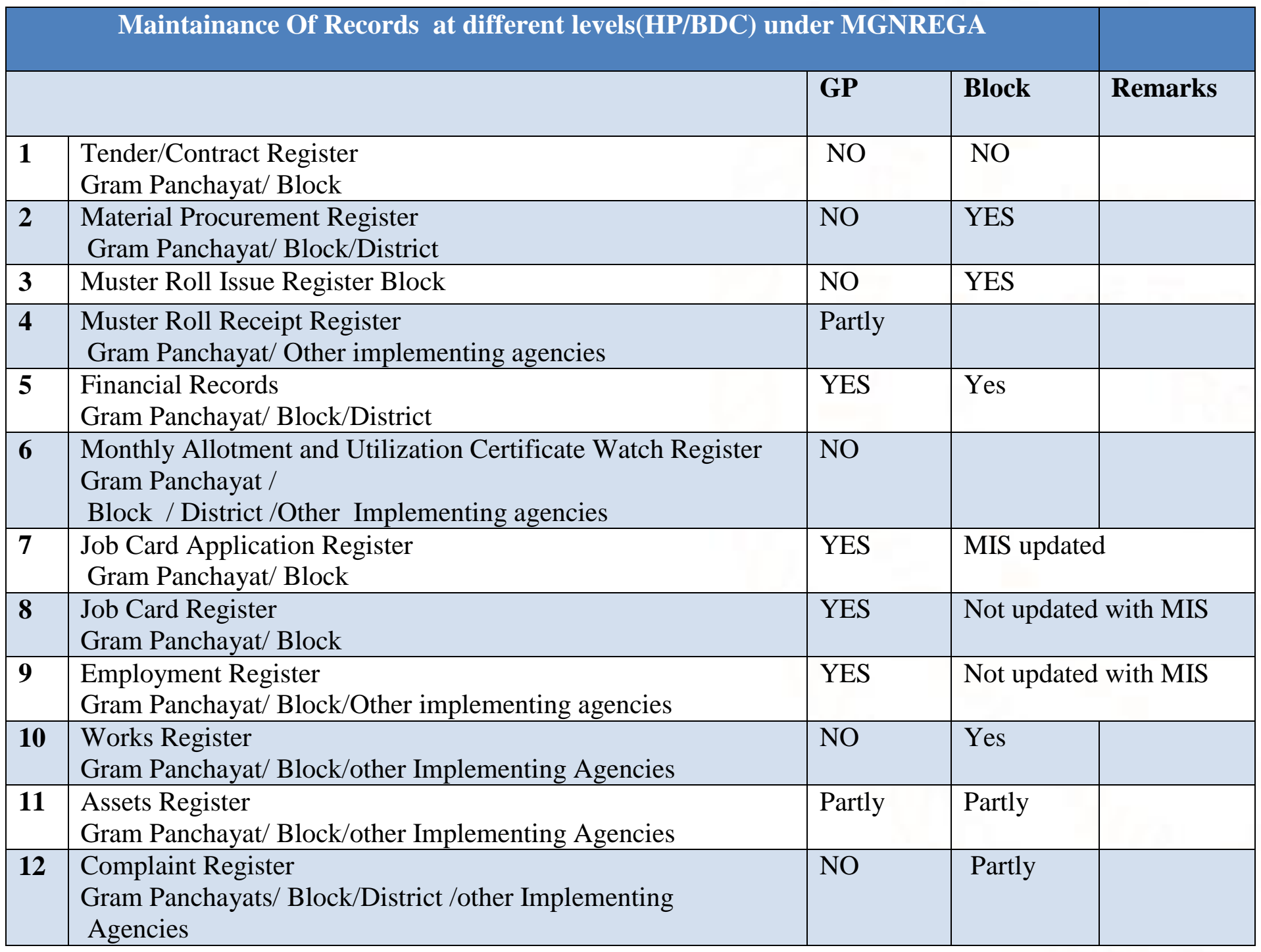

Awareness level of General public about officials to be contacted if needed.

Issue/Activity\% age of Respondents who Know to whom Contact

1. You need a job card:

2. Demand for work :

3. Delay in payment of wages:

4. Issues related to unemployment allowance:

5. Work site facilities: 
International Journal of Trend in Scientific Research and Development (IJTSRD) ISSN: 2456-6470

6. Methods of seeking work (Wage Rate/ Piece Rate): $\quad 14 \%$

7. Role of Gram Sabha in MGNREGS: $8 \%$

8. Social Audit : $3 \%$

9. Role of Contractor and Mechanism of their Selection: $\quad 0 \%$

10. Rozgar Dewas/ Employment Guarantee Day: 0\%

11. Permissible works under MGNREGA: Less than $1 \%$

(Source field Work)

\section{DETAILS OF WORKS TAKEN UP IN CONTRADITION TO MGNREGA PERMISIBLE WORKS ${ }^{[4]}$}

\begin{tabular}{|l|l|l|l|}
\hline Halqa & $\begin{array}{l}\text { \% age of negative } \\
\text { works taken up }\end{array}$ & $\begin{array}{l}\text { \% of Permissible } \\
\text { Individual benefit } \\
\text { works taken up }\end{array}$ & $\begin{array}{l}\text { \% age of permissible } \\
\text { works taken up under } \\
\text { convergence }\end{array}$ \\
\hline Achgoose & 25 & 1 & 0 \\
\hline Arigam B & 15 & 0 & 0 \\
\hline Drabgam A & 20 & 0 & 0 \\
\hline Kalampora & 35 & 2 & 0 \\
\hline Nikas & 17 & 2 & 0 \\
\hline Sangerwani A & 2 & 0 & 0 \\
\hline
\end{tabular}

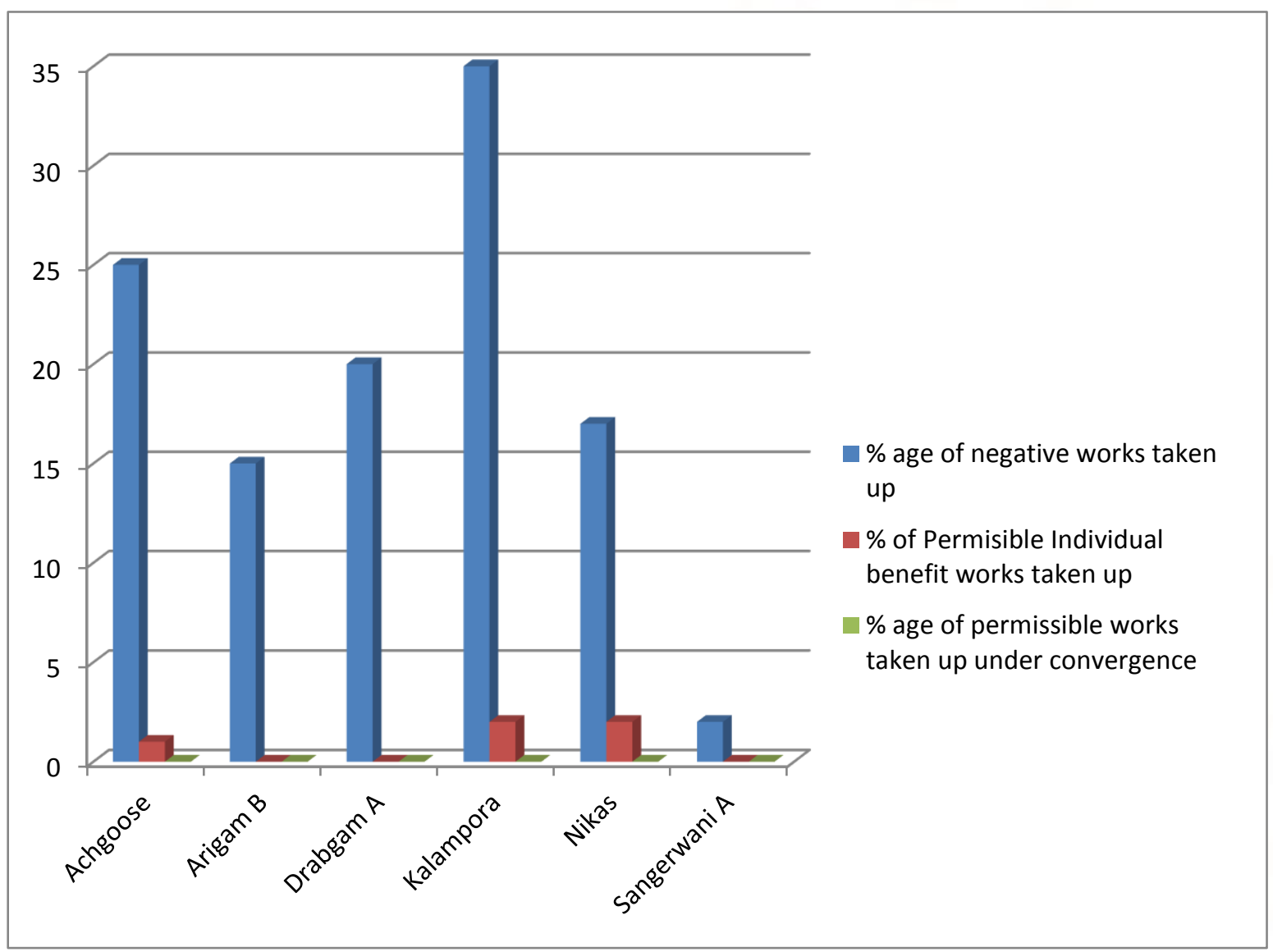




\begin{tabular}{|c|c|c|c|c|c|}
\hline \multicolumn{6}{|c|}{ Overall Satisfaction of people with respect to MGNREGA on different aspects } \\
\hline $\begin{array}{c}\text { Highly } \\
\text { Satisfied }\end{array}$ & $\begin{array}{c}\text { Some what } \\
\text { Satisfied }\end{array}$ & $\begin{array}{c}\text { Highly } \\
\text { Unsatisfied }\end{array}$ & $\begin{array}{c}\text { Some what } \\
\text { Unsatisfied }\end{array}$ & Indifferent & $\begin{array}{c}\text { Total } \\
\text { Respondents }\end{array}$ \\
\hline 56 & 65 & 37 & 65 & 23 & 246 \\
\hline $22.76 \%$ & $26.42 \%$ & $15.04 \%$ & $26.42 \%$ & $9.36 \%$ & $100 \%$ \\
\hline
\end{tabular}

Source (Field Study)

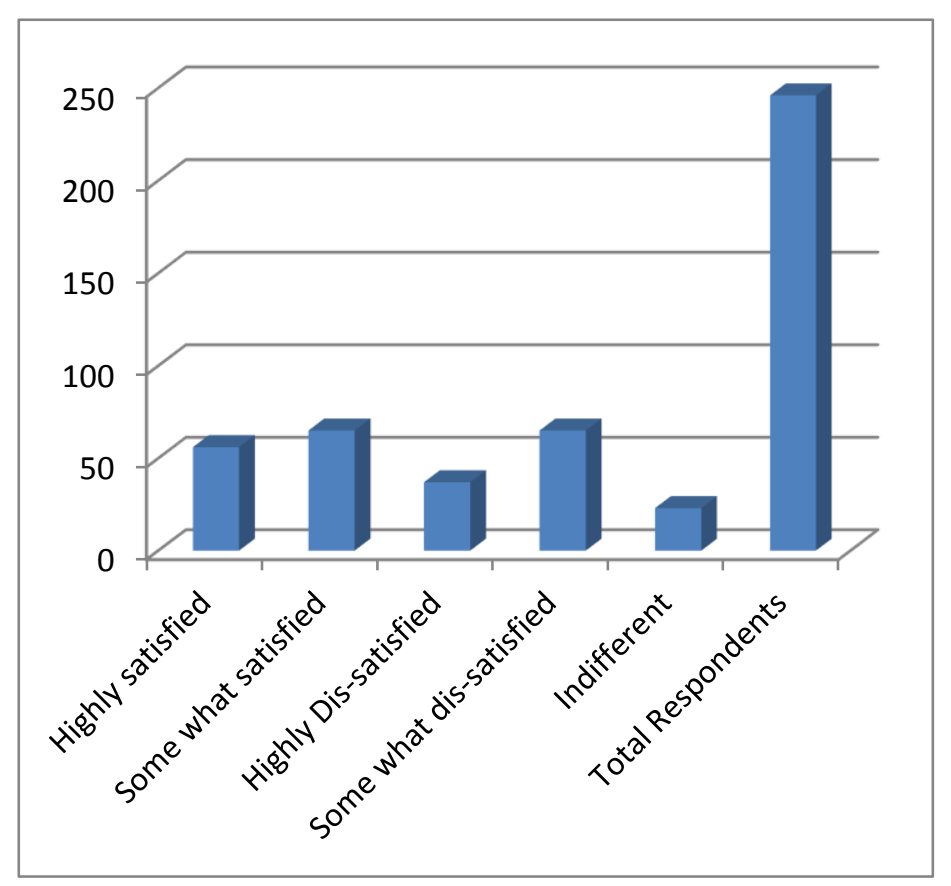

Area of Block Keller in district Pulwama is mostly comprised of tribal population and their economic status is very low as compared to others. They are surrounded by problems because economically, educationally they are counted among the people whose income is below the standard of living. Orthodoxy and illiteracy are causes of poverty, but some of the developmental programme started by the government has brought noticed changes like the Guaranteed Act. The said act has in real sense provided soft corner to those who were without job in the areas. No doubt the wages are very low but still they earned something. To a greater extent has helped the working class to have a pace with other sections of society. The act has stopped the migration of working class comprised of tribal land tillers, labourers, masons, carpenters etc. Obviously they used to migrate because of non availability of work. But now the work for them is available at their doorstep. The earned income has brought structural changes and has also strengthened their status. In order to make the act more viable and attractive the rates should be fixed a fresh, so that more and more people can be inclined towards the new employment sector.

\section{CONCLUSION}

1. The mechanism of awareness (capacity Building) needs to be strengthened and awareness camps must be conducted in every Gram Panchayat, in addition capacity building workshops need to be conducted for all the stake holders of MGNREGA at all levels including the technical staff.

2. Conduct of Gram sabhas is important in order to ensure the participation of people, but to deepen democracy and have realistic and logical plan formulation which in turn will bring transparency and accountability. The planning must be structured, need based and within the parameters of the scheme and the mechanism of concurrent monitoring need to be put in place at an earliest.

3. Base line survey needs to be conducted to assess the quantum and time of demand for works which will check duplication of job cards on one hand and ensure timely allotment of works and payments to the labourers on the other hand. Timely payments in light of the provisions of the Act ( i.e. within 15 days up to maximum ) is a distant dream as on date because in almost $98 \%$ cases timely payment is not being made as advocated in the Act.

4. State must formulate is own scheme in light of the MGNREGA Act and Operational Guidelines in vogue of the scheme keeping its geographical, topographical and demographical and other aspects into consideration

5. Work site facilities which are non existent need to be taken care to strengthen social security net and ensure dignity of the individual.

6. Mechanism of Social Audit needs to be strengthened with all institutional arrangements. 
7. Priority need to be given to those works which aid to conserve and strengthen natural resource base and in turn will have economic multiplier effect on the income and production levels.

8. The permissible works allowed on the land or homestead of SC/ST/ Small Farmers/Marginal farmers/ IAY beneficiaries/ beneficiaries of land reforms / women headed households/ forest Rights Act beneficiaries need to be taken care properly and the poorest of the poor should get the preference by adopting the PIP methodology.(Participatory Identification of the Poor ).

9. Creation of counter Productive and negative works need to be checked.

10. Expenditure on works in the negative list and counter productive if any made be recovered from person(s) responsible for approving and executing the work at different levels.

11. Maintain ace of records is very poor and need to be taken care and timely checking of these records should be ensured at all levels.

12. All others institutional arrangements as prescribed and advocated by the Act need to be put in place without further delay.

\section{REFERENCES}

1. India, Ministry of Rural Development. The National Rural Employment Guarantee Act 2005 (NREGA): Operational guidelines. New Delhi.

2. India Ministry of Rural Development, The National Rural Employment Guarantee Act 2005 (MGNREGA): Operational guidelines 4rth Edition 2013

3. Mannual of NREGS-JK scheme.

4. Annual Review Reports block Keller for the years 2008 to 2013

5. J\&K Department of Rural Development Kashmir "Targets and Achievements" through Quarterly Magazine "Dehat Sudhar" Issue June 2013.

6. <http://nrega.nic.in/NREGA_guidelinesEng.pdf>. Accessed March 06, 2016.

7. IGNOU study Material for the Course MRD102 Rural Development Programmes

8. Mathur , Yojna A Developmental Magazine August, 2008, Article on Fulfilling the Promise.

9. Singh R. P,Yojna A Developmental Magazine, August 2008 Article on Two Years On NREGA.

10. Pal M, Kurukshetra A Journal on Rural Development, October 2014 . 